\title{
PENGARUH KOMPENSASI DAN KOMUNIKASI TERHADAP SEMANGAT KERJA KARYAWAN PADA HOTEL PURI DAJUMA RESORT
}

\author{
Ni Luh Sri Widani \\ Jurusan Pendidikan Ekonomi \\ Universitas Pendidikan Ganesha \\ Singaraja, Indonesia \\ e-mail: nlsriwidani@gmail.com
}

\begin{abstract}
Abstrak
Penelitian ini bertujuan untuk mengetahui pengaruh kompensasi dan komunikasi terhadap semangat kerja karyawan pada Hotel Puri Dajuma Resort secara parsial dan simultan. Jenis penelitian ini merupakan penelitian deskriptif kuantitatif. Data dikumpulkan dengan metode kuesioner dan data selanjutnya dianalisis menggunakan analisis regresi linier berganda menggunakan SPSS 16.0 for Windows. Hasil penelitian menunjukkan bahwa secara parsial kompensasi berpengaruh signifikan terhadap semangat kerja, yang ditunjukkan dengan nilai t-hitung $=6,011>$ t-tabel $=1,677$ dan nilai probabilitas uji t 0,000 yang lebih kecil dari $\alpha=0,05$; secara parsial komunikasi berpengaruh signifikan terhadap semangat kerja, yang ditunjukkan dengan nilai t-hitung $=4,632>$ t-tabel $=1,677$ dan nilai probabilitas uji t 0,000 yang lebih kecil dari $\alpha=0,05$; secara simultan kompensasi dan komunikasi berpengaruh signifikan terhadap semangat kerja, yang ditunjukkan dengan nilai $F$-hiung $=89,298>$ F-hitung $=3,190$ dan nilai probabilitas uji $F$ 0,000 yang lebih kecil dari $\alpha=0,05$.
\end{abstract}

Kata kunci: kompensasi, komunikasi, semangat kerja karyawan.

\begin{abstract}
This research was aimed to identify the effect of compensation and communication on the employee morale of Hotel Puri Dajuma Resort partially and simultaneously. This research was quantitative descriptive research. The data collected by questionnaires methods and then analyzed by multiple linear regression analysis using SPSS 16.0 for Windows. The results showed that partially compensation had a significant effect on the employee morale, as indicated by value of t-test $=6.011>$ t-table $=1.677$ and probability value of $\mathrm{t}$ test $0.000<\alpha=0.05$; partially communication had a significant effect on the employee morale, as indicated by value of t-test $=4.632>t$-test $=1.677$ and probability value of t-test $0.000<\alpha=0.05$; simultaneously compensation and communication had a significant effect on the employee morale, as indicated by value of F-test $=89.298>$ F-table $=$ 3.190and probability value of F- test $0.000<\alpha=0.05$.
\end{abstract}

Keywords: compensation, communication, employee morale.

\section{PENDAHULUAN}

Hotel merupakan salah satu organisasi yang berorientasi pada bisnis pariwisata. Dalam menjalankan perannya hotel memerlukan sumber daya alam, sumber daya modal, sumber daya manusia, dan sumber daya lain-lain. Salah satu sumber daya yang paling penting untuk pengelolaan sebuah hotel adalah sumber daya manusia. Menurut Hasibuan (2003:244) "sumber daya manusia adalah kemampuan terpadu dari daya pikir dan daya fisik yang dimiliki individu". Pelaku dan sifatnya dilakukan oleh keturunan dan lingkungannya, sedangkan prestasi kerjanya dimotivasi oleh keinginan untuk memenuhi kepuasannya. Sebagai modal, karyawan perlu dikelola agar tetap 
menjadi produktif. Oleh sebab itu pimpinan perusahaan harus bisa mendorong mereka agar tetap produktif dalam mengerjakan tugasnya masing-masing, dengan cara terus menerus meningkatkan semangat kerja karyawan nya, sehingga perusahaan dapat mempertahankan loyalitas karyawan guna untuk mencapai tujuan perusahaan. Produktif tidaknya seorang karyawan dapat dilihat dari semangat kerja yang dimiliki oleh karyawan tersebut.

Semangat kerja memiliki peran penting dalam menentukan kecepatan dan kualitas hasil pekerjaan karyawan semangat kerja adalah melakukan pekerjaan secara lebih giat sehingga dengan demikian pekerjaan akan dapat diharapkan lebih cepat dan lebih baik. . Menurut Tohardi (2002:425) menyatakan "bahwa ada lima alasan pentingnya semangat kerja bagi organisasi atau perusahan adalah dengan adanya semangat kerja yang tinggi dari karyawan maka pekerjaan yang diberikan kepadanya akan dapat diselesaikan dengan waktu yang lebih cepat atau singkat, dengan semangat kerja yang tinggi tentunya dapat mengurangi angka absensi (bolos), dengan semangat kerja yang tinggi pihak organisasi atau perusahaan memperoleh keuntungan dari kecilnya angka kerusakan, dengan semangat kerja yang tinggi otomatis membuat pekerja atau karyawan merasa betah bekerja dengan demikian kecil emungkinan karyawan pindah bekerja, dengan semangat kerja yang tinggi dapat mengurangi angka kecelakaan". Adapun faktor- faktor yang mempengaruhi semangat kerja menurut Nitisemito (2006:112), "adalah kepemimpinan, motivasi, komunikasi, hubungan manusiawi, kompensasi dan lingkungan kerja". Menurut penelitian dari Noviyanti (2016) dari 6 faktor yang mempengaruhi semangat kerja, kompensasi dan komunikasi merupakan faktor yang memiliki pengaruh paling besar.

Pemberian kompensasi adalah suatu cara yang dilakukan perusahaan agar karyawan mempunyai tanggung jawab terhadap perusahaannya (Nurjannah, 2013:45). Menurut Sutrisno (2009:187), "kompensasi adalah semua jenis penghargaan yang berupa uang atau bukan uang yang diberikan kepada karyawan secara layak dan adil atas jasa mereka dalam mencapai tujuan perusahaan", sedangkan menurut Hasibuan (2003:118), "kompensasi adalah semua pendapatan yang berbentuk uang,barang langsung atau tidak langsung yang diterima karyawan sebagai imbalan atas jasa yang diberikan kepada perusahaan". Menurut Rivai (2004: 358) kompensasi terbagi menjadi 2 yaitu kompensasi finansial dan kompensasi nonfinansial. Kompensasi finansial merupakan kompensasi yang diwujudkan dengan sejumlah uang kartal kepada karyawan yang bersangkutan. Sedangkan kompensasi nonfinansial adalah balas jasa yang diberikan perusahaan kepada karyawan bukan berbentuk uang tetapi berwujud fasilitas. Menurut Hasibuan (2006:120) tujuan pemberian kompensasi (balas jasa) antara lain adalah; (1) ikatan kerja sama dengan pemberian kompensasi terjalinlah ikatan kerja sama formal anatara majikan dengan karyawannya; (2) kepuasan kerja dengan balas jasa karyawan akan dapat memenuhi kebutuhan- kebutuhan fisik status sosial sehingga memperoleh kepuasan kerja dari jabatannya; (3) motivasi jika balas jasa yang diberikan cukup besar manajer akan mudah memotivasi bawahannya; (4) stabilitas karyawan; dengan program kompensasi atas prinsip adil dan layak maka stabilitas karyawan akan terjamin sehingga turn over karyawan kecil; (5) disiplin, dengan adanya pemberian balas jasa yang cukup besar maka disiplin karyawan semakin baik; (6) pengaruh serikat buruh dengan tujuan pemberian kompensasi dalam hal ini baik pengaruh serikat buruh dapat dihindari; dan (7) campur tangan pemerintah, dengan adanya pemberian kompensasi yang baik maka campur tangan pemerintah dapat dihindari dan diminimalkan.

Faktor lain yang mempengaruhi semangat kerja karyawan adalah komunikasi Noviyanti (2016:50). Menurut Wilson (2012:360), "komunikasi adalah suatu proses penyampain informasi dari 
pengirim (sender) ke penerima pesan (receiver) dengan menggunakan berbagai media yang efektif sehingga pesan tersebut dapat dengan jelas dan mudah dipahami oleh penerima pesan tersebut. Dalam kegiatan tersebut, pengirim pesan berupaya menggunakan bahasa dan memilih media yang tepat, demikian sebaliknya penerima pesan berupaya agar pesan yang diterima dapat dipahami dengan jelas sehingga ada umpan balik dari pesan tersebut.

Hotel Puri Dajuma Resort beralamat di Banjar Pasar, Desa Pekutatan, Kecamatan Pekutatan, Kabupaten Jembrana. Puri Dajuma merupakan salah satu resort yang ada di Desa Pekutatan yang tidak terlepas dari permasalahan tentang semangat kerja karyawanya. Sebagai sebuah organisasi yang bertujuan untuk menghasilkan laba, maka Hotel Puri Dajuma Resort menuntut karyawannya untuk memiliki semangat kerja yang tinggi. Namun yang terjadi dilapangan menunjukan bahwa semnagat kerja karyawan hotel mulai menurun. Tinggi rendahnya semangat kerja karyawan dapat dilihat dari tinggi rendahnya tingkat absensi karyawan tersebut. Tingkat absensi karyawan Hotel Puri Dajuma Resort dari bulan januari sampai bulan desember tahun 2016 cenderung naik turun setiap bulannya. Diketahui bulan Januari sebesar 12\%, bulan Februari sampai bulan Mei rata-rata sebesar $11 \%$, bulan Juni sampai September rata-rata sebesar 10\%, bulan Oktober sebesar $11 \%$, bulan November dan Desember sebesar $10 \%$, sehingga rata-rata tingkat absensi karyawannya sebesar 10,9\% lebih tinggi dibandingkan dengan standar maksimum tingkat absensi yang ditetapkan perusahaan terhadap kehadiran karyawan yaitu sebesar $8 \%$. Dengan demikian, hasil presentasi tingkat absensi karyawan Hotel Puri Dajuma Resort diatas $8 \%$ yang merupakan salah satu indikasi adanya masalah dalam semangat kerja karyawan Hotel Puri Dajuma Resort .

Berdasarkan hasil wawancara terhadap beberapa karyawan hotel, ada beberapa masalah yang terjadi berkaitan dengan variabel-variabel yang diteliti dalam penelitian ini. Masalah-masalah tersebut antara lain karyawan merasa kurang puas akan besarnya kompensasi yang diberikan. Kompensasi yang diberikan perusahaan masih kurang, yaitu dapat dilihat dari kompensasi finansial berupa gaji yang diterima oleh karyawan kebanyakan masih berjumlah Rp1.685.000 yang masih berada di bawah UMK kabupaten Jembrana tahun 2016, yaitu sebesar Rp1.853.687. Kemudian, kompensasi nonfinansial berupa waktu libur untuk hari raya yang diberikan oleh perusahaan dirasakan masih kurang memuaskan bagi karyawan di perusahaan ini. Adapun komunikasi yang sering digunakan pada Hotel Puri Dajuma Resort hanya komunikasi ke bawah yang dilakukan pimpinan kepada bawahannya, berupa perintah, instruksi tugas, dan informasi, sedangkan komunikasi keatas dari karyawan ke pimpinan hanya sesekali dilakukan bila karyawan membutuhkan informasi. Hal ini disebabkan karena kurang beraninya bawahan dalam menyampaikan kritik dan saran kepada atasannya.

Dari latar belakang yang telah diuraikan diatas, maka tujuan penelitian ini adalah untuk mengetahui pengaruh kompensasi dan komunikasi terhadap semangat kerja karyawan pada Hotel Puri Dajuma Resort secara parsial dan simultan.

\section{METODE}

Penelitian ini merupakan jenis penelitian kausal. Penelitian kausal adalah penelitian yang menunjukkan hubungan variabel bebas dengan variabel terikat (Sugiyono, 2011). Terdapat tiga variabel yang digunakan dalam penelitian ini yaitu dua variabel bebas dan satu variabel terikat. Variabel bebas dalam penelitian ini adalah adalah kompensasi $\left(X_{1}\right)$ dan komunikasi $\left(X_{2}\right)$, sedangkan variabel terikat dalam penelitian ini adalah semangat kerja (Y). Penelitian ini dilakukan guna mengetahui: pengaruh kompensasi terhadap semangat kerja karyawan pada Hotel Puri Dajuma Resort, pengaruh komunikasi terhadap semangat kerja karyawan pada Hotel Puri Dajuma Resort, dan pengaruh kompensasi dan 
komunikasi terhadap semangat kerja karyawan pada Hotel Purii Dajuma Resort. Subjek penelitian ini adalah karyawan Hotel Puri Dajuma Resort yang bejumlah 51 orang, sedangkan yang menjadi objek dalam penelitian ini adalah kompensasi, komunikasi, dan semangat kerja karyawan Hotel Puri Dajuma Resort. Jenis data penelitian ini adalah data kuantitatif, yaitu data berupa angka-angka yang diperoleh dari jawaban responden mengenai kuesioner kompensasi, komunikasi, dan semangat kerja karyawan Hotel Puri Dajuma Resort. Data primer pada penelitian ini adalah data yang diperoleh langsung dari subjek yang diteliti. Data primer penelitian ini berupa kuesioner kompensasi, komunikasi, dan semangat kerja karyawan Hotel Puri Dajuma Resort.

Adapun metode pengumpulan data yang digunakan dalam penelitian ini adalah metode kuesioner. Metode kuesioner digunakan untuk mendapatkan data tentang kompensasi, komunikasi, dan semangat kerja karyawan Hotel Puri Dajuma Resort. Data yang telah dikumpulkan digunakan sistem skor, dimana jawaban pertanyaan diberi skor dengan menggunakan skala likert. Skala likert merupakan skala yang digunakan untuk mengukur, sikap, pendapat, dan persepsi seseorang atau sekelompok orang tentang fenomena sosial (Sugiyono, 2013). Setiap pernyataan disediakan 5 (lima) alternatif jawaban, yaitu (1) apabila jawaban Sangat Setuju (SS) diberi skor 5; (2) apabila jawaban Setuju (S) diberi skor 4; (3) apabila jawaban Kurang Setuju (KS) diberi skor 3; (4) apabila jawaban tidak setuju (TS) diberi skor 2; dan (5) apabila jawaban sangat tidak setuju (STS) diberi skor 1.

Kuesioner sebagai instrumen pengumpulan data sebelum digunakan untuk mengumpulkan data di lapangan terlebih dahulu harus diuji tingkat validitas dan reliabilitasnya. Untuk menguji tingkat validitas dan reliabilitas instrumen penelitian akan diujikan kepada 30 responden. Validitas adalah untuk melihat kecermatan alat ukur, yaitu mengukur apa yang akan diukur. Dalam penelitian ini, suatu kuesioner dinyatakan valid, jika pertanyaan maupun pernyataan pada kuesioner mampu untuk mengungkapkan sesuatu yang akan diukur oleh kuesioner tersebut. Pengujian validitas dalam penelitian ini dilakukan dengan menggunakan Person Correlation yang terdapat dalam program SPSS 16.0 for Windows. Menurut Ghozali (2011), suatu pertanyaan dikatakan valid jika tingkat signifikasinya di bawah 0,05 . Reliabilitas berkaitan dengan keterandalan suatu indikator. Informasi yang ada pada indikator ini tidak berubah-ubah, atau bisa disebut dengan kosisten. Uji reabilitas dilakukan untuk menguji apakah jawaban dari responden konsisiten. Suatu angket dikatakan reliable jika jawaban seseorang terhadap pertanyaan adalah konsisten atau stabil dari waktu ke waktu. Menurut Ghozali (2011), pengujian realibilitas dalam penelitian ini dilakukan dengan menggunakan Alpha Cronbach yang terdapat dalam program SPSS 16.0 for Windows. Suatu instrumen dikatakan reliabel jika memiliki nilai Alpha Cronbach $>0,70$.

Analisis data dilakukan untuk menguji hipotesis yang diajukan, yaitu untuk mengetahui ada tidaknya hubungan antara variabel bebas $(X)$ dengan variabel terikat $(\mathrm{Y})$, sedangkan teknik analisis data yang digunakan dalam penelitian ini adalah regresi linier berganda. Menurut Sugiyono (2011), regresi linier berganda digunakan untuk mengetahui pengaruh antara dua variabel bebas atau lebih terhadap variabel terikat.. Sebelum dilakukan pengujian analisis regresi linear berganda, maka dilakukan pengujian prasyarat, yaitu uji asumsi klasik yang terdiri dari uji normalitas, uji heteroskedastisitas, dan uji multikolinearitas.

Uji normalitas digunakan untuk menguji apakah variable terikat, variabel bebas atau keduanya mempunyai distribusi normal atau tidak. Menurt Ghozali (2011), model regresi dikatakan baik apabila memiliki distribusi normal atau mendekati normal. Metode yang digunakan untuk melakukan pengujian ini adalah Statistic Kolgomorov-Smirnov. Kriteria yang digunakan adalah dengan membandingkan antar tingkat signifikansi 
yang didapat dengan tingkat signifikan (a), dikatakan berdistribusi normal apabila probabilitas $>\alpha$.

Menurut Ghozali (2011), uji heteroskedastisitas bertujuan untuk menguji apakah dalam sebuah model regresi terjadi ketidaksamaan varians dari residual Uji dari satu pengamatan satu ke pengamatanyang lain. Jika varians dari residu atau dari satu pengamatan ke pengamatan yang lain tetap, maka disebut homokedastisitas, dan jika varians berbeda maka disebut heteroskedastisitas. Cara untuk mendeteksi heteroskedastisitas adalah dengan melihat grafik scatterplot.

Uji multikolonieritas bertujuan untuk menguji apakah pada model regresi ditemukan adanya korelasi antar variable bebas (Ghozali, 2011). Model regresi yang baik seharusnya tidak terjadi korelasi di antara variable bebas. Pengujian ada tidaknya gejala multikolonieritas dilakukan dengan memperhatikan nilai VIF (Variance Inflation Factor) dan Tolerance .Apabila nilai VIF berada dibawah 10 dan nilai Tolerance lebih dari 0,1 maka diambil kesimpulan bahwa model regresi tersebut tidak terdapat gejala problem multikolonieritas (Ghozali, 2011).

Teknik analisis data yang digunakan adalah analisis regresi linier berganda.Dari hasil analisis regresi linier berganda dapat diketahui persamaan garis regresi untuk mengetahui pengaruh kompensasi dan komunikasi terhadap semangat kerja karyawan dengan menggunakan analisis koefisien betasebagai berikut.

$$
Y=a+\beta_{1} X_{1}+\beta_{2} X_{2}+\varepsilon
$$

Keterangan:

$$
\begin{array}{ll}
Y & =\text { Variabel Terikat (Semangat } \\
& \text { Kerja) } \\
\alpha & =\text { Koefisien Konstanta } \\
\beta_{1}, \beta_{2}= & \text { Koefisien Regresi } \\
X_{1} & =\text { Variabel Bebas (Kompensasi) } \\
X_{2} & =\text { Variabel Bebas (Komunikasi) } \\
\varepsilon & =\text { Disturbance Error }
\end{array}
$$

Pengujian hipotesis secara parsial menggunakan uji t. Uji t dilakukan untuk melihat signifikansi pengaruh independen secara individu terhadap variabel dependen.Pengujian ini dilakukan dengan membandingkan t-hitung dengan t-tabel. Adapun langkah-langkah pengujiannya, yaitu: (1) perumusan hipotesis, menentukan tingkat signifikan (a) yaitu sebesar 5\%, (3) menentukan kriteria penerimaan atau penolakan $\mathrm{H}_{0}$ dengan melihat nilai signifikan. Jika signifikan < $5 \%$ maka $\mathrm{H}_{0}$ ditolak dan jika signifikan > $5 \%$ maka $\mathrm{H}_{0}$ diterima, dan pengambilan keputusan.

Pengujian hipotesis secara simultan menggunakan uji F. Uji F dilakukan untuk melihat signifikansi pengaruh independen secara simultan terhadap variabel dependen.Pengujian ini dilakukan dengan membandingkan F-hitung dengan F-tabel. Adapun langkah-langkah pengujiannya, yaitu: (1) perumusan hipotesis, (2) menentukan tingkat signifikan (a) yaitu sebesar $5 \%$, (3) menentukan kriteria penerimaan atau penolakan $\mathrm{H}_{0}$ dengan melihat nilai signifikan. Jika signifikan < $5 \%$ maka $\mathrm{H}_{0}$ ditolak dan jika signifikan > $5 \%$ maka $\mathrm{H}_{0}$ diterima, dan (4) pengambilan keputusan.

Analisis determinasi bertujuan untuk mengetahui atau menentukan seberapa besar pengaruh kompensasi dan komunikasi terhadap semangat kerja karyawan pada Hotel Puri Dajuma Resort. Untuk menghitung koefisien determinasi $\left(R^{2}\right)$ menggunakan program SPSS 16.0 for Windows.

\section{HASIL DAN PEMBAHASAN Hasil}

Berdasarkan hasil analisis data menunjukkan bahwa secara parsial pengaruhkompensasiterhadap semangat kerja karyawan pada Hotel Puri Dajuma Resort dapat diketahui dengan menggunakan uji t. Perhitungan uji $t$ menggunakan bantuan program SPSS 16.0 for Windows dan pengujian hipotesis dilakukan pada taraf signifikansi $5 \%$. Hasil uji t dapat dilihat pada Tabel 1. 
Tabel 1. Hasil Uji t untuk Pengaruh Kompensasi Terhadap Semangat Kerja Karyawan

\begin{tabular}{|c|c|c|c|c|c|c|}
\hline \multirow{3}{*}{\multicolumn{2}{|c|}{ Model }} & \multicolumn{2}{|c|}{ Unstandardized } & \multicolumn{3}{|l|}{ Standardized } \\
\hline & & \multicolumn{2}{|c|}{ Coefficients } & \multirow{2}{*}{$\begin{array}{c}\text { Coefficients } \\
\text { Beta }\end{array}$} & \multirow[t]{2}{*}{$\mathrm{t}$} & \multirow[t]{2}{*}{ Sig. } \\
\hline & & B & Std. Error & & & \\
\hline 1 & (Constant) & 8,298 & 3,352 & & 2,475 & 0,017 \\
\hline & Kompensasi & 0,694 & 0,116 & 0,546 & 6,011 & 0,000 \\
\hline
\end{tabular}

a. Dependent Variable: Semangat Kerja Karyawan

Berdasarkan Tabel 1, diperoleh nilai thitung $=6,011$ dengan nilai $p$-value sebesar 0,000 . Nilai t-hitung $=6,011$ lebih besar dari t-tabel $=1,677$ dan $p$-value sebesar 0,000 lebih kecil dari $\alpha=0,05$, maka keputusannya $\mathrm{H}_{0}$ ditolak. Jadi, dapat disimpulkan bahwa secara parsial terdapat pengaruh yang signifikan antara kompensasi terhadap semangat kerja karyawan pada Hotel Puri Dajuma Resort.

Berdasarkan hasil analisis data menunjukkan bahwa secara parsial pengaruh komunikasi terhadap semangat kerja karyawan pada Hotel Puri Dajuma Resort dapat diketahui dengan menggunakan uji t. Perhitungan uji t menggunakan bantuan program SPSS 16.0 for Windows dan pengujian hipotesis dilakukan pada taraf signifikansi 5\%. Hasil uji $t$ dapat dilihat pada Tabel 2 .

Tabel 2. Hasil Uji tuntuk PengaruhKomunikasi Terhadap Semangat Kerja Karyawan

\begin{tabular}{|c|c|c|c|c|c|c|}
\hline & \multirow{3}{*}{ Model } & \multicolumn{2}{|c|}{ Unstandardized } & \multirow{2}{*}{$\begin{array}{c}\text { Standardized } \\
\text { Coefficients }\end{array}$} & \multirow{3}{*}{$\mathrm{t}$} & \multirow{3}{*}{ Sig. } \\
\hline & & & & & & \\
\hline & & B & Std. Error & Beta & & \\
\hline 1 & (Constant) & $\begin{array}{l}8,298 \\
0,497\end{array}$ & $\begin{array}{l}3,352 \\
0107\end{array}$ & 0.421 & $\begin{array}{c}2,475 \\
4.632\end{array}$ & $\begin{array}{l}0,017 \\
0,000\end{array}$ \\
\hline
\end{tabular}

a. Dependent Variable: Semangat Kerja Karyawan

Berdasarkan Tabel 2, diperoleh nilai thitung $=4,632$ dengan nilai $p$-value sebesar 0,000 . Nilai t-hitung $=6,011$ lebih besar dari t-tabel $=1,677$ dan $p$-value sebesar 0,000 lebih kecil dari $\alpha=0,05$, maka keputusannya $\mathrm{H}_{0}$ ditolak. Jadi, secara parsial terdapat pengaruh yang signifikan antara komunikasiterhadap semangat kerja karyawan pada Hotel Puri Dajuma Resort.

Pengaruh kompensasi dan komunikasi terhadap semangat kerja karyawan pada Hotel Puri Dajuma Resort secara simultan diuji dengan menggunakan uji $F$. Perhitungan uji $F$ menggunakan bantuan program SPSS 16.0 for Windows dan pengujian hipotesis dilakukan pada taraf signifikansi 5\%. Hasil uji F dapat dilihat pada

Tabel

Tabel 3.Hasil Uji F

\begin{tabular}{llccccc}
\hline & Model & Sum of Squares & $d f$ & Mean Square & $\mathrm{F}$ & Sig. \\
\hline Regression & 961,604 & 2 & 480,802 & 89,298 & 0,000 \\
& Residual & 258,445 & 48 & 5,384 & & \\
& Total & 1220,049 & 50 & & & \\
\hline
\end{tabular}

a. Dependent Variable: Semangat Kerja Karyawan

b. Predictors: (Constant), Komunikasi, Kompensasi

Berdasarkan Tabel 3, diperoleh nilai

F-hitung $=89,298>$ F-tabel $=3,190$ dengan nilai $p$-value sebesar 0,000 . Nilai $p$ - value 0,000 lebih kecil dari 0,05 , maka keputusannya $\mathrm{H}_{0}$ ditolak. Jadi,secara simultan terdapat pengaruh yang signifikan 
antara kompensasi dan komunikasi terhadap semangat kerja karyawan pada Hotel Puri Dajuma Resort.

Besar pengaruh variabel kompensasi dan komunikasi terhadap semangat kerja karyawan pada Hotel Puri Dajuma Resort dapat diketahui dari koefisien determinasi, yang ditunjukkan dengan nilai adjusted $R$ Square. Hasil analisis koefisien determinasi dapat disajikan pada Tabel 4.

Tabel 4. Hasil Analisis Koefisien Determinasi

\begin{tabular}{ccccc}
\hline Model & $\mathrm{R}$ & $\mathrm{R}$ Square & Adjusted R Square & Std. Error of the Estimate \\
\hline 1 & 0,888 & 0,788 & 0,779 & 2,320 \\
\hline
\end{tabular}

a. Predictors: (Constant), Komunikasi, Kompensasi

Berdasarkan Tabel 4 ditunjukkan bahwa besar hasil perhitungan koefisien determinasi pada pengaruh kompensasi dan komunikasi terhadap semangat kerja karyawan pada Hotel Puri Dajuma Resort secara simultan sebesar 0,779. Dengan demikian, besarnya sumbangan pengaruh untuk variable kompensasi dan komunikasi terhadap semangat kerja karyawan secara simultan adalah sebesar $77,9 \%$. Hal ini berarti semangat kerja karyawan Hotel Puri Dajuma Resort sebesar $77,9 \%$ dipengaruhi oleh variable kompensasi dan komunikasi, sedangkan sisanya sebesar 21,1\% dipengaruhi oleh factor lain yang tidak termasuk dalam penelitian ini.

Berdasarkan hasil analisis regresi linier berganda, dapat diketahui persamaan garis regresi untuk mengetahui pengaruh kompensasi dan komunikasi terhadap semangat kerja karyawan pada Hotel Puri Dajuma Resort dengan menggunakan analisis koefisien beta. Hasil perhitungan konstanta dan koefisien beta dapat dilihat pada

Tabel

Tabel 5. Hasil Analisis Koefisien Beta

\begin{tabular}{|c|c|c|c|c|c|c|}
\hline & \multirow[t]{2}{*}{ Model } & \multicolumn{2}{|c|}{$\begin{array}{l}\text { Unstandardized } \\
\text { Coefficients }\end{array}$} & \multirow{2}{*}{$\begin{array}{c}\text { Standardized } \\
\text { Coefficients } \\
\text { Beta } \\
\end{array}$} & \multirow[t]{2}{*}{$\mathrm{t}$} & \multirow[t]{2}{*}{ Sig. } \\
\hline & & $B$ & Std. Error & & & \\
\hline \multirow[t]{3}{*}{1} & (Constant) & 8,298 & 3,352 & & 2,475 & 0,017 \\
\hline & Kompensasi & 0,694 & 0,116 & 0,546 & 6,011 & 0,000 \\
\hline & Komunikasi & 0,497 & 0,107 & 0,421 & 4,632 & 0,000 \\
\hline
\end{tabular}

a. Dependent Variable: Semangat Kerja Karyawan

Berdasarkan perhitungan regresi linier berganda pada Tabel 5, maka didapat hasil persamaan regresi sebagai berikut.

$Y=a+\beta_{1} X_{1}+\beta_{2} X_{2}+\varepsilon$

$Y=8,298+0,694 X_{1}+0,497 X_{2}+\varepsilon$

Keterangan:

$\mathrm{Y}=$ semangat kerja karyawan

$\mathrm{X}_{1}=$ kompensasi

$\mathrm{X}_{2}=$ komunikasi

Interpretasi dari model regresi di atas adalah konstanta 8,298 menunjukkan bahwa jika variable bebas kompensasi $\left(X_{1}\right)$ dan komunikasi $\left(X_{2}\right)$ sama dengan nol, maka nilai semangat kerja (Y) adalah sebesar 8,298 satuan. Nilai koefisien $\beta_{1}=$ 0,694 menunjukkan bahwa terdapat pengaruh positif antara variabel kompensasi $\left(X_{1}\right)$ terhadap variabel semangat kerja $(Y)$ sebesar 0,694 . Hal ini berarti apabila variabel kompensasi $\left(X_{1}\right)$ naik sebesar 1 satuan dan nilai variabel bebas lainnya adalah konstan, maka nilai variabel semangat kerja (Y) akan mengalami peningkatan sebesar 0,694 satuan. Nilai koefisien $\beta_{2}=0,497$ menunjukkan bahwa terdapat pengaruh positif antara variabel komunikasi $\left(\mathrm{X}_{2}\right)$ terhadap variabel semangat kerja (Y) sebesar 0,497. Hal ini berarti apabila variabel komunikasi $\left(\mathrm{X}_{2}\right)$ naik sebesar 1 satuan dan nilai variabel bebas lainnya adalah konstan, maka nilai variabel semangat kerja (Y) akan mengalami peningkatan sebesar 0,497 satuan.

\section{Pembahasan}


Hasil penelitian menunjukkan bahwa terdapat pengaruh yang siginifikan antara kompensasi terhadap semangat kerja karyawan. Persamaan regresi punya arah koefisien positif sebesar 0,694. Pengaruh positif menunjukkan bahwa hubungan kompensasi dengan semangat kerja karyawan adalah searah. Jika kompensasi semakin tinggi, maka semangat kerja karyawan juga semakin tinggi. Terdapat pengaruh yang signifikan antara kompensasi terhadap semangat kerja karyawan, yang ditunjukkan dengan nilai probabilitas uji t sebesar 0,000 lebih kecil dari 0,05.

Hasil analisis data dalam penelitian ini menunjukkan bahwa kompensasi memiliki pengaruh parsial yang signifikan terhadap semangat kerja karyawan Hotel Puri Dajuma Resort. Hasil penelitian ini mendukung teori dari Nitisemito (2006) yang menyatakan bahwa jumlah kompensasi yang diberikan besar pengaruhnya terhadap semangat dan kegairahan kerja. Temuan ini juga sejalan dengan penelitian yang dilakukan oleh Noviyanti (2016) yang berjudul Faktorfaktor yang Mempengaruhi Semangat Kerja Karyawan pada Lembaga Pekreditan Desa (LPD) Desa Sumberkima di Kecamatan Gerokgak Tahun 2015. Dan Nurjannah (2013) yang berjudul Pengaruh Kompensasi Terhadap Semangat Kerja Karyawan Tetap pada PT. Perkebunan Nusantara XIV (Persero) Pola Kerja Sama Luwu.

Pengaruh Komunikasi Secara Parsial Terhadap Semangat Kerja Karyawan Hotel Puri Dajuma Resort. Hasil penelitian menunjukkan bahwa terdapat pengaruh yang siginifikan antara komunikasi terhadap semangat kerja karyawan. Persamaan regresi punya arah koefisien positif sebesar 0,497. Pengaruh positif menunjukkan bahwa hubungan komunikasi dengan semangat kerja karyawan adalah searah.Jika komunikasi semakin baik, maka semangat kerja karyawan semakin tinggi. Terdapat pengaruh yang signifikan antara komunikasi terhadap semangat kerja karyawan, yang ditunjukkan dengan nilai probabilitas uji $\mathrm{t}$ sebesar 0,000 lebih kecil dari 0,05.
Hasil analisis data dalam penelitian ini menunjukan bahwa komunikasi memiliki pengaruh parsial yang signifikan terhadap semangat kerja karyawan Hotel Puri Dajuma Resort. Hasil penelitian ini mendukung teori dari Handoko (2001) yang menyatakan melalui komunikasi maka dapat memberikan keterangan tentang pekerjaan yang membuat pegawai bertindak dengan rasa tanggung jawab pada diri sendiri dan pada waktu yang bersamaan dapat mengembangkan semnagat kerjanya. Temuan ini juga sejalan dengan penelitian yang dilakukan oleh Permaningratna (2013) yang berjudul Pengaruh Lingkungan Fisik dan Komunikasi Terhadap Semangat Kerja Karyawan pada PT. Saka Agung Abadi Denpasar.

Pengaruh kompensasi dan Komunikasi secara simultan terhadap semangat kerja karyawan Hotel Puri Dajuma Resort. Hasil penelitian menunjukkan bahwa secara simultan terdapat pengaruh yangsignifikan antara kompensasi dan komunikasi terhadap semangat kerja karyawan, yang ditunjukkan dengan nilai probabilitas uji $\mathrm{F}$ sebesar 0,000 lebih kecil dari $0,05 . \mathrm{Hal}$ ini menunjukkan bahwa jika kompensasi dan komunikasi semakin baik, maka semangat kerja karyawan semakin tinggi.

Hasil analisis data dalam penelitian ini menunjukan kompensasi dan komunikasi mempunyai pengaruh simultan yang signifikan terhadap semangat kerja karyawan Hotel Puri Dajuma Resort. Hasil penelitian ini mendukung teori dari Nitisemito (2006), yang menyatakan halhal yang mempengaruhi semangat kerja karyawan adalah jumlah dan komposisi dari kompensasi yang diberikan, penempatan yang tepat, latihan rasa aman di masa depan, mutasi, promosi, lingkungan kerja dan komunikasi. Temuan ini juga sejalan dengan penelitian yang dilakukan oleh Noviyanti (2016) yang berjudul Faktor-faktor yang Mempengaruhi Semangat Kerja pada Lembaga Perkreditan Desa (LPD) Desa Sumberkima di Kecamatan Gerokgak Tahun 2015.

\section{SIMPULAN DAN SARAN Simpulan}


Berdasarkan hasil analisis data dan pembahasan hasil penelitian maka dapat ditarik simpulan sebagai berikut .(1) Kompensasi berpengaruh signifikan secara parsial terhadap semangat kerja karyawan Hotel Puri Dajuma Resort. Hal ini berarti pemberian kompensasi secara layak kepada karyawan akan mempengaruhi semangat kerja karyawan tersebut; (2) Komunikasi berpengaruh signifikan secara parsial terhadap semangat kerja karyawan Hotel Puri Dajuma Resort. Hal ini berarti dengan adanya komunikasi yang baik anatara pimpinan dengan karyawan dan komunikasi yang baik antar karyawan dengan karyawan akan mempengaruhi semangat kerja karyawan tersebut; (3) Kompensasi dan komunikasi berpengaruh signifikan secara simultan terhadap semangat kerha karyawan Hotel Puri Dajuma Resort. Hal ini berarti kompensasi dan komunikasi secara bersama- sama mempengaruhi semangat kerja karyawan Hotel Puri Dajuma Resort.

\section{Saran}

Berdasarkan simpulan diatas, maka dapat dikemukakan beberapa saran sebagai berikut. (1) Bagi perusahaan untuk tetap memperhatikan apa yang dibutuhkan oleh karyawan agar dapat meningkatkan semangat kerja karyawan baik berupa kompensasi dan komunikasi. Meningkatkan semangat kerja karyawan dapat dilakukan dengan memperhatikan pemberian kompensasi kepada karyawan baik berupa kompensasi finansial dengan cara memberikan gaji sesuai dengan lamanya pengabdian di hotel dan juga tetap memperhatikan UMK yang berlaku di kabupaten Jembrana dan juga kompensasi nonfinansial dengan cara memberikan liburan hari raya yang cukup bagi karyawan yang merayakan hari raya.Selain itu, Hotel Puri Dajuma juga harus memperhatikan komunikasi yang terjadi antar karyawan dengan atasan dan juga komunikasi antar karyawan dengan karyawan, sebaiknya pihak hotel secara rutin memberikan briefing sebelum memulai pekerjaan agar karyawan mendapatkan arahan kerja yang jelas sesuai dengan tujuan perusahaan.Bagi peneliti selanjutnya diharapkan dapat mengembangkan penelitian ini di masa yang akan datang dengan mempertimbangkan aspek lainnya yang mempengaruhi semangat kerja.

\section{DAFTAR PUSTAKA}

Ghozali, Imam. 2011. Aplikasi Analisis Multivariate dengan Program SPSS. Semarang: Badan Penerbit Universitas Diponegoro.

Handoko, T. Hani. 2001. Manajemen Personalia dan Sumber Daya Manusia. Yogyakarta: BPFE Yogyakarta.

Hasibuan, Malayu S. P. 2003. Manajemen Sumber Daya Manusia. Jakarta: Bumi Aksara.

Nitisemito, Alex S. 2006. Manajemen Personalia, Manajemen Sumber Daya Manusia. Jakarta: Ghalia Indonesia.

Noviyanti, Putu. 2016. Faktor-faktor yang Mempengaruhi Semangat Kerja Karyawan pada Lembaga Perkreditan Desa (LPD) Desa Sumberkima di Kecamatan Gerokgak Tahun 2015. Skrips Tidak diterbitkan). Jurusan Pendidikan Ekonomi Universitas Pendidikan Ganesha Singaraja.

Nurjannah.2013. Pengaruh Kompensasi Terhadap Semangat Kerja Karyawan Tetap pada PT.Perkebunan Nusantara XIV (Persero) Pola Kerja Sama Luwu.Jurnal Equilibrium, 3 (2): 207-212.

Permaningratna, Putu Duwita. 2013. Pengaruh Lingkungan Fisik dan Komunikasi Terhadap Semangat Kerja Karyawan pada PT.Saka Agung Abadi Denpasar.Skripsi (Tidak diterbitkan). Jurusan Pendidikan Ekonomi Universitas Pendidikan Ganesha Singaraja.

Sugiyono. 2011. Metode Penelitian Kuantitatif, Kualitatif dan $R$ \& $D$. Bandung: Afabeta.

2013. Metode Penelitian Manajemen. Bandung: Alfabeta. 
p-ISSN : 2599-1418

Jurnal Pendidikan Ekonomi Undiksha

e-ISSN : 2599-1426

Volume 10 No. 1 Tahun 2018

Sutrisno, Edi. 2009. Manajemen Sumber Daya Manusia. Jakarta: Kencana Prenada Media Group.

Tohardi, Ahmad. 2002. Pemahaman Praktis Manajemen Sumber Daya Manusia. Bandung: Mandar Maju.

Wilson, Bangun. 2012. Manajemen Sumber Daya Manusia. Bandung: Erlangga. 